\title{
A multi-centennial record of past floods and earthquakes in Valle d'Aosta, Mediterranean Italian Alps
}

\author{
Bruno Wilhelm ${ }^{1}$, Hendrik Vogel ${ }^{2}$, and Flavio S. Anselmetti ${ }^{2}$ \\ ${ }^{1}$ University Grenoble Alpes, CNRS, IRD, INP-G, Institut des Géosciences de l'Environnement, \\ 38000 Grenoble, France \\ ${ }^{2}$ Institute of Geological Sciences and Oeschger Centre for Climate Change Research, \\ University of Bern, 3012 Bern, Switzerland \\ Correspondence to: Bruno Wilhelm (bruno.wilhelm@univ-grenoble-alpes.fr)
}

Received: 8 November 2016 - Discussion started: 21 November 2016

Revised: 30 March 2017 - Accepted: 13 April 2017 - Published: 8 May 2017

\begin{abstract}
Mediterranean Alpine populations are particularly exposed to natural hazards like floods and earthquakes because of both the close Mediterranean humidity source and the seismically active Alpine region. Knowledge of longterm variability in flood and earthquake occurrences is of high value since it can be useful to improve risk assessment and mitigation. In this context, we explore the potential of a lake-sediment sequence from Lago Inferiore de Laures in Valle d'Aosta (Northern Italy) as a long-term record of past floods and earthquakes. The high-resolution sedimentological study revealed 76 event layers over the last ca. 270 years; 8 are interpreted as most probably induced by earthquakes and 68 by flood events. Comparison to historical seismic data suggests that the recorded earthquakes are strong (epicentral Medvedev-Sponheuer-Kárník (MSK) intensity of VIIX) and/or close to the lake (distance of $25-120 \mathrm{~km}$ ). Compared to other lake-sediment sequences, Lago Inferiore de Laures sediments appear to be regionally the most sensitive to earthquake shaking, offering a great potential to reconstruct the past regional seismicity further back in time. Comparison to historical and palaeoflood records suggests that the flood signal reconstructed from Lago Inferiore de Laures sediments represents the regional and (multi-)decadal variability of summer-autumn floods well, in connection to Mediterranean mesoscale precipitation events. Overall, our results reveal the high potential of Lago Inferiore de Laures sediments to extend the regional earthquake and flood catalogues far back in time.
\end{abstract}

\section{Introduction}

Natural hazards (e.g. earthquakes, floods, landslides) are of particular concern for societies as they cause widespread loss of life, damage to infrastructure and economic deprivation (e.g. Munich Re Group, 2003). The frequency of both geological (i.e. earthquakes) and hydrological (i.e. floods) events varies in time mainly as a function of tectonic processes and climatic regimes, respectively. Such long-term changes need to be taken into account for more accurate risk assessments. This becomes even more crucial in the context of global warming, which is expected to lead to a modification of the hydrological cycle and associated floods (IPCC, 2013). However, available instrumental time series generally cover a short time span, precluding a comprehensive knowledge of the tectonic and climatic-related variability. In this respect, historical and natural archives have been widely studied to extend earthquake and flood catalogues further back in time (e.g. Guidaboni et al., 2007; Rizza et al., 2011; Brázdil et al., 2012; Ballesteros-Cánovas et al., 2015; Benito et al., 2015; Denniston et al., 2015; Ratzov et al., 2015). Among them, lake sediments have shown to be valuable archives as they record past events in a continuous and high-resolution mode (e.g. Lauterbach et al., 2012; Wilhelm et al., 2012a; Strasser et al., 2013; Wirth et al., 2013; Amman et al., 2015; Van Daele et al., 2015). The greater hydraulic energy of flooded rivers increases their capacity to erode and transport sediments. Downstream, lakes may act as sediment traps, resulting in the deposition of a coarser-grained layer that will be preserved in time (e.g. Gilli et al., 2012; Schillereff et al., 

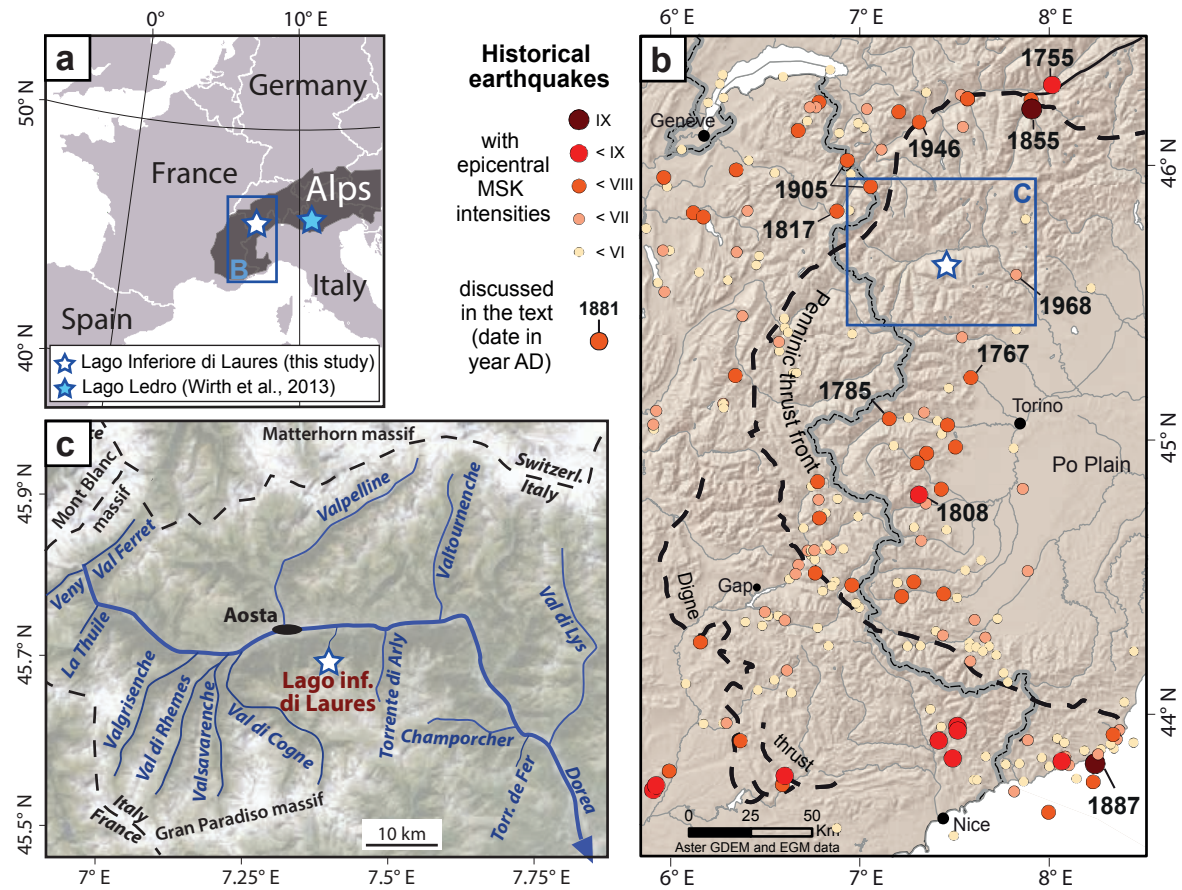

Figure 1. (a) Location of Lago Inferiore de Laures in the Mediterranean Italian Alps, with (b) locations of historical earthquakes with epicentral MSK intensity above IV. The earthquake catalog is provided by the database SisFrance (http://infoterre.brgm.fr/; Lambert and Levret-Albaret, 1996; Scotti et al., 2004). (c) Location of Lago Inferiore de Laures catchment area in the hydrological network of Vallee d'Aosta that is regularly affected by floods as documented by Mercalli et al. (2003).

2014). In the case of earthquakes, ground shaking may disturb lake sediments by triggering coseismic in situ deformation or post-seismic deposits related to subaquatic mass movements of slope sediments and resuspension (e.g. Avşar et al., 2014; Van Daele et al., 2015). Identification and dating of all "event layers" in sediment cores enable us to reconstruct past event occurrences over centuries to millennia. Recently, some studies have also developed methods to reconstruct the magnitude of past events. The magnitude of past flood events may be reconstructed through grain size (e.g. Schiefer et al., 2011; Lapointe et al., 2012; Wilhelm et al., 2015; Schillereff et al., 2014) or through the total volume of sediments transported and deposited during the flood (e.g. Jenny et al., 2014; Wilhelm et al., 2015). Reconstruction of past earthquake magnitudes and location is approached by comparing regional records of seismic-induced deposits (e.g. Strasser et al., 2006; Wilhelm et al., 2016b) or through the deposit's spatial extent and thickness (Howarth et al., 2014; Moernaut et al., 2014).

The southern European Alps (Northern Italy) are particularly harmed by natural hazards such as floods and earthquakes (e.g. Boschi et al., 2000; Guzetti and Tonelli, 2004; Eva et al., 2010) due to the proximity of both the Mediterranean Sea and the seismically active Alpine region. The Mediterranean Sea is the primary moisture source for orographic precipitation on the southern flank of the Alps (e.g. Buzzi and Foschini, 2000; Lionello et al., 2012). Spatially restricted convective and spatially more exhaustive cyclonic precipitation events may lead to catastrophic floods (Gaume et al., 2009; Marchi et al., 2010), as for instance occurred in October 2000 or June 1957 (Ratto et al., 2003). Moreover, the south-western European Alps are in a seismogenic region that experienced strong earthquakes with macroseismic Medvedev-Sponheuer-Kárník (MSK) intensities up to IX and estimated magnitudes higher than 6, e.g. the Ligurian earthquake in $1887\left(M_{\mathrm{w}}=6.8\right.$; Larroque et al., 2012) and the Visp earthquake in $1855\left(M_{\mathrm{w}}=6.2\right.$; Fäh et al., 2011; Fig. 1),

In this context, the present study aims at exploring the potential of a lake sequence as recorder of past floods and earthquakes in the western Italian Alps. This is undertaken by studying the high-elevation sediment sequence of Lago Inferiore de Laures, Valle d'Aosta.

\section{Study site}

Valle d'Aosta is located at the foot of the Mont Blanc and Monte Rosa massifs, north of the vast Italian Po Plain and $\sim 180 \mathrm{~km}$ north of the Mediterranean Sea (Fig. 1). Lago Inferiore de Laures ( $2450 \mathrm{~m}$ a.s.l.; $45^{\circ} 41^{\prime} \mathrm{N}, 7^{\circ} 24^{\prime} \mathrm{E}$ ) is a small, high-elevation lake located on the north-facing slope of Vallee d'Aosta (Fig. 1c). Due to the high elevation of the catchment, only the area surrounding the lake is covered by alpine meadow vegetation, which is impacted by grazing ac- 


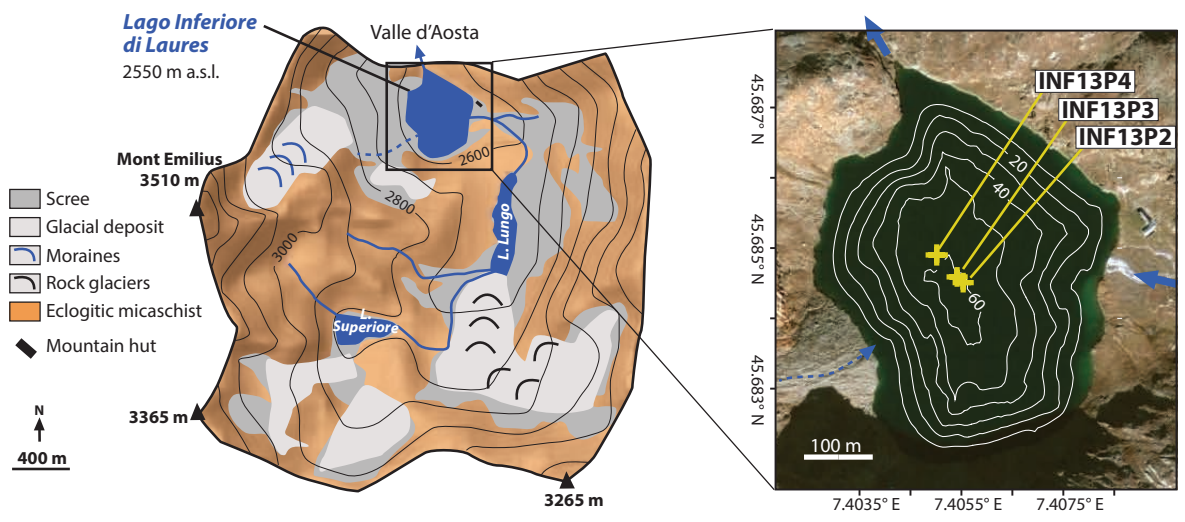

Figure 2. Geological and geomorphological characteristics of the Lago Inferiore de Laures catchment area (left panel). Bathymetric map of Lago Inferiore de Laures and coring sites (right panel).

tivity. Most of the catchment is covered by bedrock and scree. Rock is mainly made of eclogitic micaschist, which was eroded by small glaciers in the western and southern parts of the catchment as evidenced by the presence of glacial deposits and moraines (Fig. 2). These glaciers have disappeared and only a rock glacier is still active in the south-eastern part of the catchment. The catchment is mainly drained by the mountain stream that crosses Lago Superiore and Lago Lungo before entering Lago Inferiore. These two upper lakes act as two sediment traps and, therefore, all the upper part of the catchment barely contributes to the detrital inputs in Lago Inferiore. Detrital inputs are mainly provided by (i) the lower part of the main stream and its eastern tributary and (ii) a temporary stream that drains glacial deposits west from the lake. This results in two distinct major detrital input sources to the lake, as suggested by the aerial and subaquatic deltas built on the eastern and western lake shores. Mobilization of detrital material is restricted to summer months and the beginning of autumn (June/July to mid-November) when the lake ice cover is absent and catchment soils are thawed and free of snow cover.

\section{Methods}

\subsection{Core description and logging}

In autumn 2013, a bathymetric survey with a single-beam echosounder was carried out at Lago Inferiore and revealed a narrow flat basin in the centre of the lake with a maximum water depth of $60.7 \mathrm{~m}$ (Fig. 2). Three long gravity cores up to $62 \mathrm{~cm}$ have been retrieved from the depocentre of the lake. The uppermost $13 \mathrm{~cm}$ of core INF13P2 was disturbed during the coring. The three cores were split lengthwise and the visual macroscopic features of each core were examined in detail to determine the different sedimentary facies. Based on these facies, a stratigraphic correlation was carried out between the three cores to document the spatial extent and succession of the different facies over the lake basin.

High-resolution images and gamma-ray attenuation porosity evaluator (GRAPE) data were acquired on a Geotek ${ }^{\text {TM }}$ multi-sensor core logger (Institute of Geological Sciences, University of Bern). The bulk density is obtained at a $5 \mathrm{~mm}$ downcore resolution. X-ray analyses on the core INF13P3 were carried out on an Itrax ${ }^{\mathrm{TM}}$ (Cox Analytical Systems) Xray fluorescence (XRF) core scanner (Institute of Geological Sciences, University of Bern), using a Molybdenum tube, set to $30 \mathrm{kV}, 35 \mathrm{~mA}$ with a $10 \mathrm{~s}$ count time and a $1 \mathrm{~mm}$ sampling step. The scattered incoherent (Compton) radiation of the $\mathrm{X}$-ray tube $\left(\mathrm{Mo}_{\text {inc }}\right)$ varies with bulk element mass/sediment density (Croudace et al., 2006) and, therefore, provides a high-resolution proxy for sediment density (e.g. Wilhelm et al., 2016a). Mo inc values were averaged at a $5 \mathrm{~mm}$ resolution for correlation with the GRAPE, which resulted in a linear, positive and significant correlation $\left(r=0.88, p<10^{-4}\right)$. This allowed using $\mathrm{Mo}_{\text {inc }}$ as a proxy of sediment density for identifying millimetre-scale event layers, e.g. flood and mass-movement deposits. Event layers are characterized by higher density because of the high amount of detrital material provided in a short time (e.g. Støren et al., 2010; Gilli et al., 2012; Wilhelm et al., 2012b).

Grain-size analyses were performed on core INF13P3 using a Malvern Mastersizer 2000 (Institute of Geography, University of Bern) at a $5 \mathrm{~mm}$ continuous interval. Before the grain-size analysis, the samples were treated in a temperate bath of diluted (30\%) hydrogen peroxide for 3 days to remove the organic matter. The complete removal of the organic matter was checked through smear-slide observations. Grain-size analyses of the detrital material were performed to characterize the transport-deposition dynamics of the deposits (e.g. Passega, 1964; Wilhelm et al., 2013, 2015). 


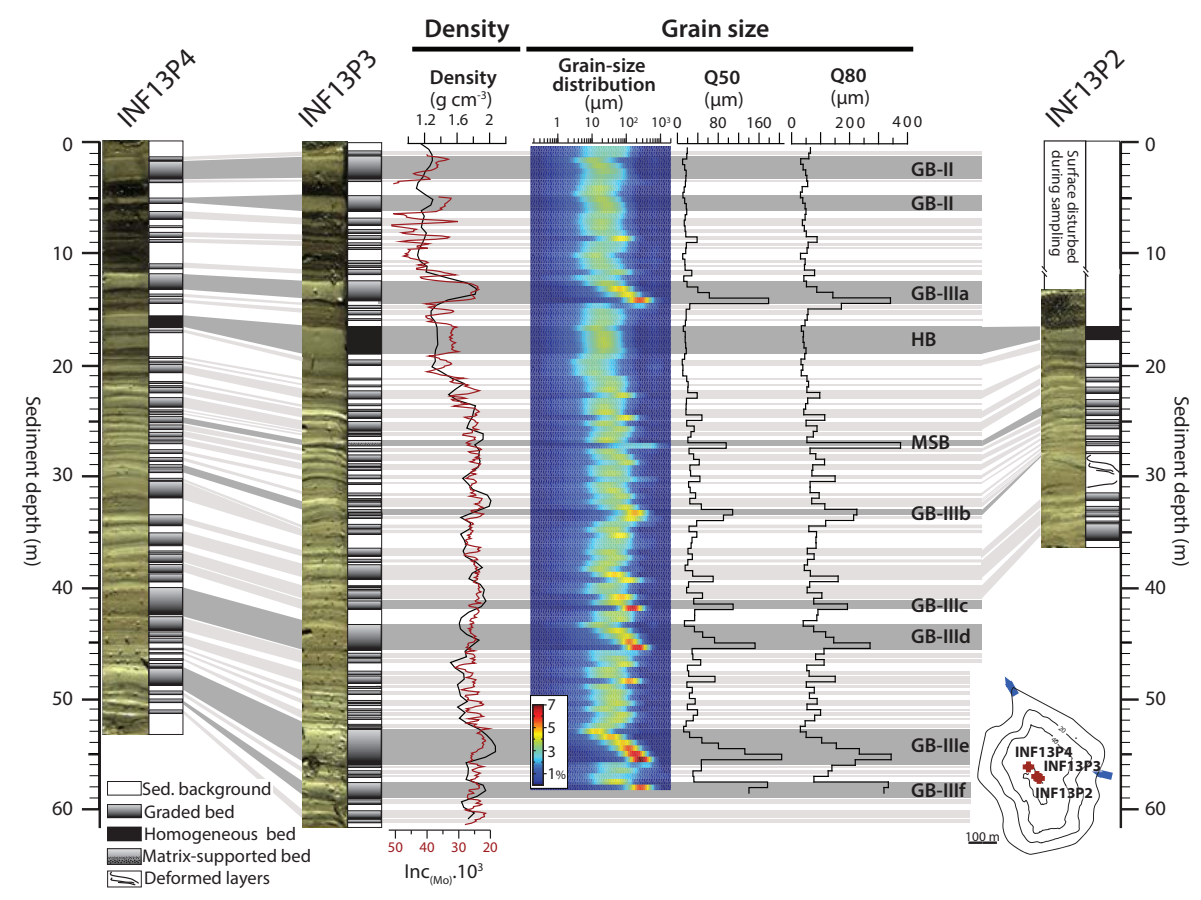

Figure 3. Lithological descriptions of cores and stratigraphic correlations based on sedimentary facies. Variability in grain-size distribution is shown for the core INF13P3. The density measurements performed by gamma-ray attenuation are shown close to Moinc, used as a highresolution density proxy. The horizontal bars highlights the stratigraphical correlation between cores with a distinction between two probable triggers of deposits (light versus dark grey) as discussed in Sect. 5.1 and 5.2.

\subsection{Dating methods}

To date the lake sequence over the last century, shortlived radionuclides $\left({ }^{226} \mathrm{Ra},{ }^{210} \mathrm{~Pb},{ }^{137} \mathrm{Cs}\right)$ were measured by gamma spectrometry at EAWAG (Dübendorf, Switzerland). The core INF13P3 was sampled following a non-regular step of $1 \pm 0.2 \mathrm{~cm}$, matching the facies boundaries. The ${ }^{137} \mathrm{Cs}$ measurements generally allow two main chronostratigraphic markers to be located: the fallout of ${ }^{137} \mathrm{Cs}$ from atmospheric nuclear weapon tests culminating in 1963 and the fallout of ${ }^{137}$ Cs from the Chernobyl accident in 1986 (Appleby et al., 1991). ${ }^{226} \mathrm{Ra}$ is measured as a proxy for the supported ${ }^{210} \mathrm{~Pb}$ in order to calculate the unsupported ${ }^{210} \mathrm{~Pb}$ that corresponds to the excess ${ }^{210} \mathrm{~Pb}$ (e.g. Schmidt et al., 2014). The decrease in excess ${ }^{210} \mathrm{~Pb}\left({ }^{210} \mathrm{Pbex}\right)$ and the constant flux/constant sedimentation (CFCS) model allow a mean sedimentation rate to be calculated (Goldberg, 1963). The standard error of the linear regression of the CFCS model is used to assess the uncertainty of the sedimentation rate. The ${ }^{137} \mathrm{Cs}$ chronostratigraphic markers are then used to control the validity of the ${ }^{210} \mathrm{~Pb}$-based sedimentation rate.

In addition to short-lived radionuclides, historical lead $(\mathrm{Pb})$ contaminations were also used to control the ${ }^{210} \mathrm{~Pb}$ based chronology (e.g. Renberg et al., 2001). In order to identify lead contamination, we used the geochemical measurements carried out on the Itrax ${ }^{\mathrm{TM}}$ XRF core scanner on core INF13P3. Pb intensities were normalized to a well-measured detrital element, i.e. titanium (Ti), to disentangle natural and human-induced changes in $\mathrm{Pb}$. Recorded $\mathrm{Pb}$ variations were compared to historical lead emissions in Switzerland (Weiss et al., 1999), the closest place to the studied site where lead emissions are well documented.

\section{Results}

\subsection{Description of the sedimentary deposits}

The sediment consists of a finely bedded, greenish brown mud mainly composed of detrital material with grain sizes in the silt-clay fraction and amorphous organic matter. Smearslide observations reveal that the organic matter content increases upcore, concurrently to the dark brown colour of these deposits (Fig. 3). These fine-grained deposits, representing the background hemipelagic sedimentation, are interrupted by 77 beds characterized by rather coarse material, lower organic matter content and higher density. According to several studies providing a comprehensive overview of event layers (e.g. Mulder and Cochonat, 1996; Gani, 2004; Van Daele et al., 2015; Wilhelm et al., 2016b), the 77 beds represent short-term depositional events and they correspond to 74 graded beds (GBs), 1 matrix-supported bed (MSB), 1 homogeneous bed (HB) and 1 deformed layer (Fig. 3). 


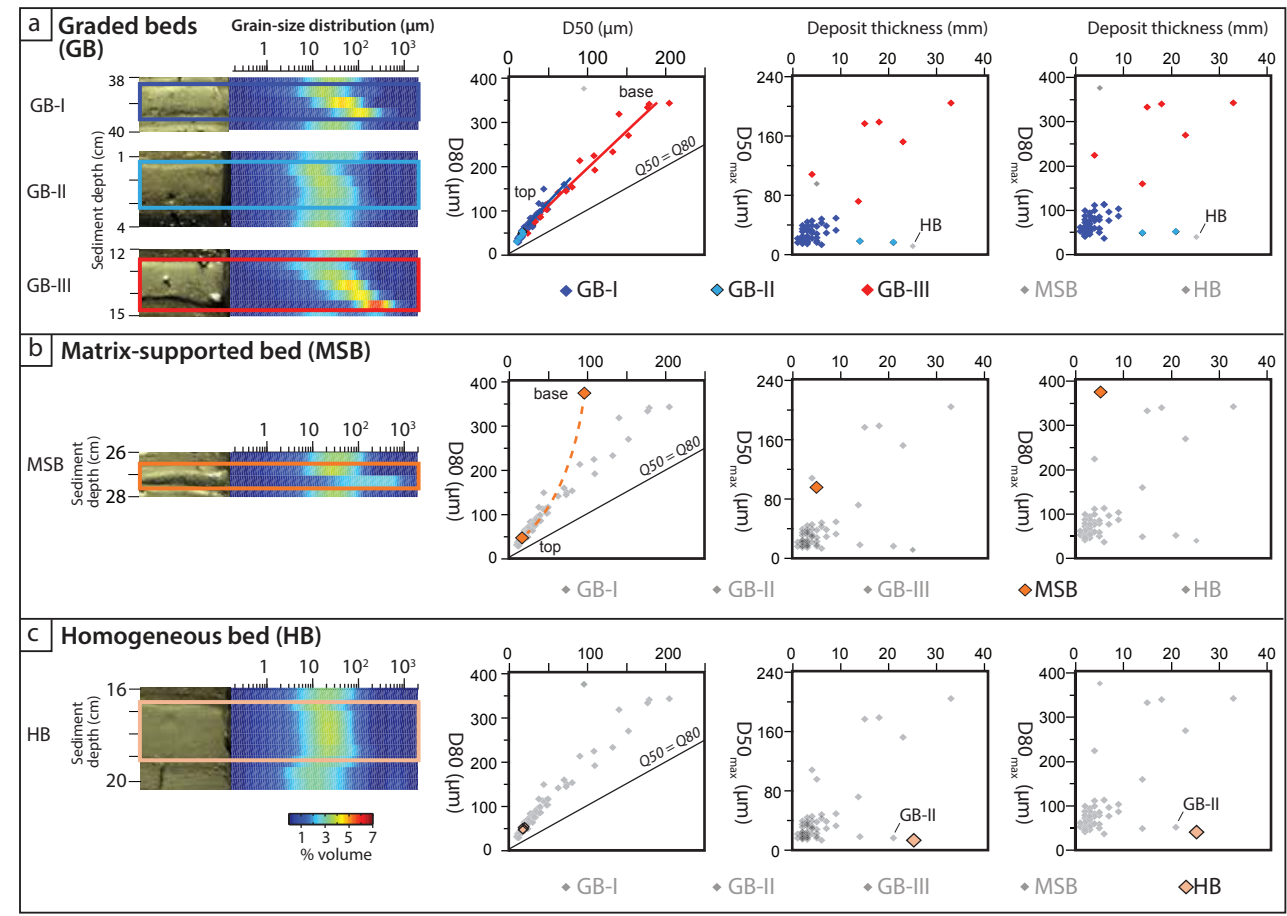

Figure 4. Close-eye views of event layers (left) and their positions in a Passega-type (Q50 vs. Q80) diagram as well as in "percentile vs. deposit thickness" diagrams (right) for the graded beds (a), the matrix-supported bed (b) and the homogenous bed (c).

The 74 GBs are all characterized by a sharp and coarsegrained base, a fining-upward trend and a thin, whitish finegrained capping layer. There is no evidence for erosive bases. The stratigraphic correlation reveals that almost all GBs appear in the three cores. Only four GBs identified in cores INF13P3 $(33.3-35 \mathrm{~cm})$ and INF13P4 $(29.6-32 \mathrm{~cm})$ are missing in core INF13P2. In core INF13P2, the four missing GBs stratigraphically correspond to a deformed layer $(28-30 \mathrm{~cm}$; Fig. 3).

The Passega-type (D50 vs. D80) diagram highlights a steady decrease of both the median (D50) and the coarse percentile (D80) from the base to the top of the GBs (Fig. 4a). This confirms the visually identified fining-upward trend of all GBs. "D50 max vs. deposit thickness" and "D80 $\max$ vs. deposit thickness" diagrams (where $\mathrm{D} 50_{\max }$ and $\mathrm{D} 80_{\max }$ are defined as the highest value of D50 and D80 of each GB) suggest that the 74 GBs may be differentiated in three types (Fig. 4a). Most of the GBs (66 of 74) form a well-grouped cluster characterized by low values of thickness $(1-10 \mathrm{~mm})$, D50 $0_{\max }(10-50 \mu \mathrm{m})$ and D80 $0_{\max }(35-115 \mu \mathrm{m})$. These $66 \mathrm{GBs}$ are labelled GB-I (dark blue points, Fig. 4a). These diagrams highlight two GBs, labelled GB-II (light blue points, Fig. 4a), also characterized by a very fine grain size (D50 $\max$ of 16$18 \mu \mathrm{m}$ and $\mathrm{D} 80_{\max }$ of $\left.50-52 \mu \mathrm{m}\right)$ but a larger thickness (14$21 \mathrm{~mm}$ ) than GB-I. As a result, GB-II is characterized by an intermediate pattern between GB-I and HB. In contrast, some GBs (6 of 74; labelled GB-III; red points, Fig. 4a) are scattered in the "percentile vs. thickness" diagrams but well distinguishable from GB-I and GB-II because of both their coarser grain size (D50 of 70-200 $\mu \mathrm{m}$ and D80 of 160$350 \mu \mathrm{m}$ ) and larger thickness (from 3 to $33 \mathrm{~mm}$ ). The distinct characteristics of the three GB types suggest distinct dynamics of sediment transport and deposition and, thereby, distinct triggers (discussed in Sect. 5.1.1 and 5.2.1).

The MSB identified at $27 \mathrm{~cm}$ in core INF13P3 differs from the GBs by the poorly sorted fining-upward trend (Figs. 3 and $4 \mathrm{~b}$ ). This is well highlighted in the Passega-type diagram where the pattern is almost vertical, describing a large decrease of the coarse percentile (D80) with much less variation of the median (D50). The $2.5 \mathrm{~mm}$ thick HB identified at $17 \mathrm{~cm}$ in core INF13P3 is characterized by a sharp base, a thin, whitish fine-grained capping layer and a central part with a fine and perfectly homogeneous grain size (Figs. 3 and $4 \mathrm{c}$ ).

A $3.5 \mathrm{~cm}$ thick layer at $28 \mathrm{~cm}$ in core INF13P2 is characterized by mixed beds in the lower part and folded beds in the upper part (Fig. 3). The stratigraphic correlation reveals that this deformed layer is overlain by a thin graded bed that becomes thicker in cores INF13P3 and INF13P4. In core INF13P3, this graded bed corresponds to a GB-III (labelled GB-IIIb in Fig. 3). In addition, the stratigraphic correlation suggests that this deformed layer is not intercalated in the sediment sequence (e.g. slump) but corresponds to in situ deformation. 

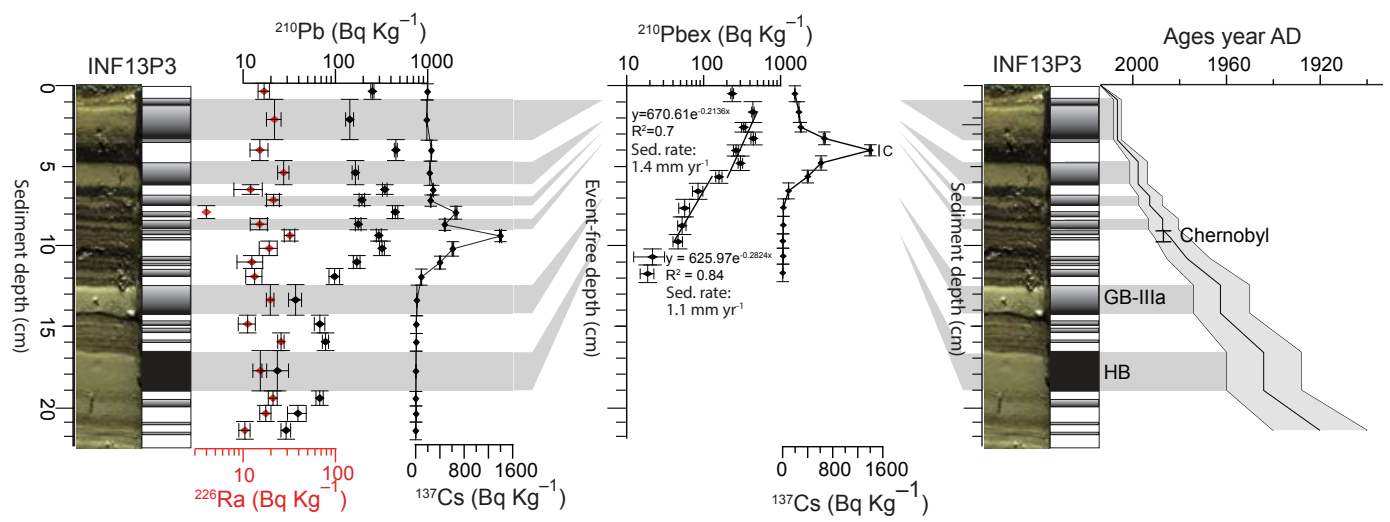

Figure 5. ${ }^{226} \mathrm{Ra},{ }^{210} \mathrm{~Pb}$ and ${ }^{137} \mathrm{Cs}$ profiles for core INF13P3 (left). Application of a CFCS model to the event-free sedimentary profile of ${ }^{210} \mathrm{Pbex}$ and the resulting age-depth relationship with $1 \sigma$ uncertainties and locations of the historic ${ }^{137} \mathrm{Cs}$ peak of Chernobyl (1986) supporting the ${ }^{210} \mathrm{~Pb}$-based ages.

\subsection{Chronology}

The excess ${ }^{210} \mathrm{~Pb}\left({ }^{210} \mathrm{Pbex}\right)$ profile in cores INF13P3 shows a steady decrease downcore in activity from 436 to $11 \mathrm{~Bq} \mathrm{~kg}^{-1}$. The profile is, however, punctuated by depths with very low values, which correspond to thick event layers (Fig. 5). We excluded ${ }^{210}$ Pbex values associated with these instantaneous deposits to construct a synthetic sediment record (Arnaud et al., 2002). The CFCS model (Goldberg, 1963) was applied to the synthetic ${ }^{210} \mathrm{Pbex}$ profile and indicates that the sequence is characterized by two periods of different sedimentation rates. Sedimentation rates shift from $1.1 \pm 0.2 \mathrm{~mm}$ year $^{-1}$ in the lower portion of the core to $1.4 \pm 0.36 \mathrm{~mm}_{\text {year }}{ }^{-1}$ in the topmost $5.5 \mathrm{~cm}$. The CFCS model-derived ages were used to develop continuous age-depth relationships for core INF13P3 (Fig. 5). A synthetic ${ }^{137} \mathrm{Cs}$ profile was built and displays a progressive increase until a peak of $1400 \mathrm{~Bq} \mathrm{~kg}^{-1}$ at $9.5 \mathrm{~cm}$ (Fig. 5). Such high ${ }^{137} \mathrm{Cs}$ values are characteristic of the fallout associated with the 1986 Chernobyl accident in the region (e.g. Vannière et al., 2013; Wilhelm et al., 2012a; Etienne et al., 2012; Wilhelm et al., 2016a). The second expected peak related to the nuclear weapon tests in 1963 cannot be as clearly defined.

The $\mathrm{Pb} / \mathrm{Ti}$ ratio shows a low background $(\leq 0.5)$ in the lower part of core INF13P3 (Fig. 6). At $21 \mathrm{~cm}$, the $\mathrm{Pb} / \mathrm{Ti}$ ratio increases and remains almost always above 0.5 upcore. From 13 to $8 \mathrm{~cm}$, it reaches high values $(>1)$ with a maximum at $10 \mathrm{~cm}(>4)$. These distinct steps mirror well historical $\mathrm{Pb}$ emissions in Switzerland with low emissions $\left(<500\right.$ tons year $\left.{ }^{-1}\right)$ until 1920 and high emissions $\left(>1000\right.$ tons year $^{-1}$ ) from the 1950 s to the 1980 s, with a maximum around 1970 (Weiss et al., 1999). The increase of $\mathrm{Pb}$ emission in the 1920s may correspond to the beginning of the use of leaded gasoline and the peak in $\mathrm{Pb}$ emission (1970s) to its maximal use (Weiss et al., 1999; Arnaud et al., 2004). These two steps in historical $\mathrm{Pb}$ contaminations, well

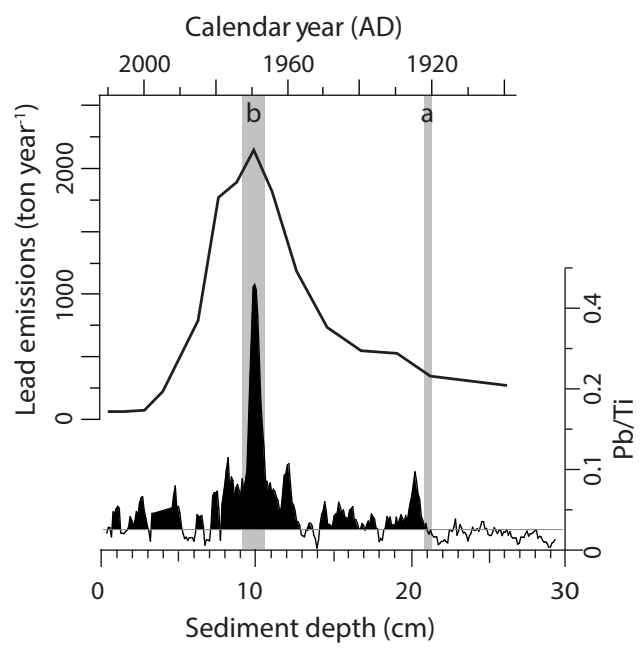

Figure 6. Historical lead $(\mathrm{Pb})$ emissions in Switzerland (from Weiss et al., 1999) compared to the $\mathrm{Pb} / \mathrm{Ti}$ ratio measured in core INF13P3.

marked in the $\mathrm{Pb} / \mathrm{Ti}$ ratio, may thus be used as additional chronological markers.

Overall, the good chronological agreement between these independent markers $\left({ }^{137} \mathrm{Cs}\right.$ peak and $\mathrm{Pb}$ peaks) and the ${ }^{210} \mathrm{~Pb}$-derived ages supports the validity of our age-depth model (Fig. 7). The extrapolation of the CFCS model-derived ages suggest that core INF13P3 covers the $\sim 270$ years (Fig. 7). 


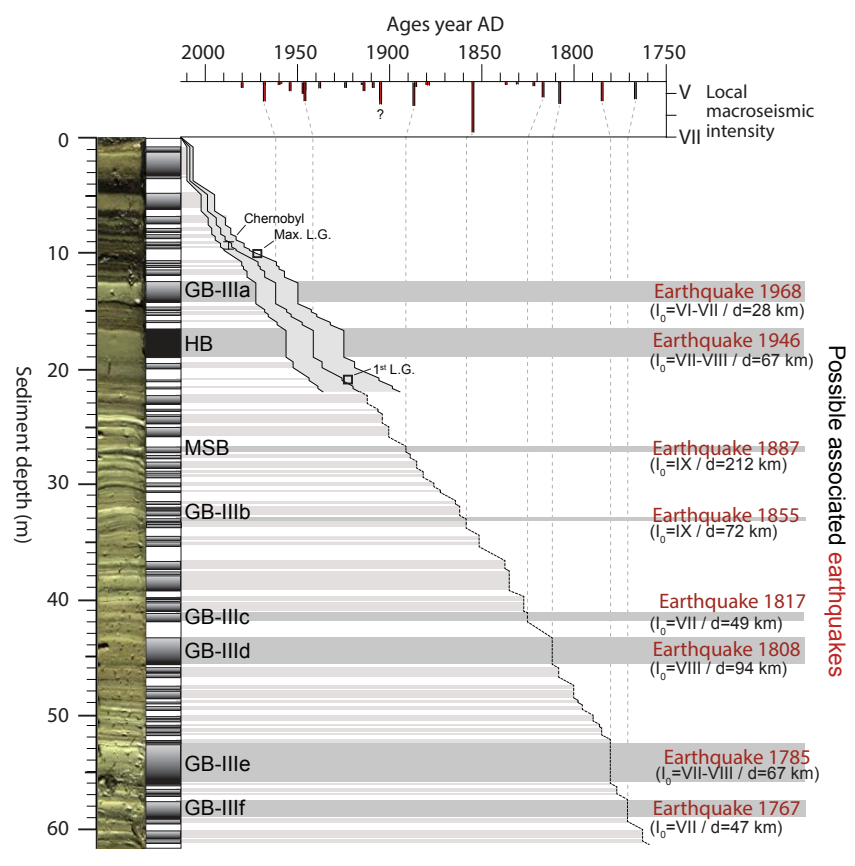

Figure 7. Age-depth relationship of core INF13P3 based on the ${ }^{210} \mathrm{~Pb}$-based sedimentation rate (with $1 \sigma$ uncertainties) for the last century and based on the extrapolation of this sedimentation rate for the lower part of the core. The three chronological markers supporting the ${ }^{210} \mathrm{~Pb}$-based sedimentation are shown: the ${ }^{137} \mathrm{Cs}$ peak associated with the Chernobyl accident (1986), the first use of leaded gasoline (1920s) and its maximal use (1970s). Labels (GBIII, HB and MSB) correspond to the mass-movement-induced deposits. Historical earthquakes, possibly associated with these massmovement-induced deposits, are indicated with their respective epicentral MSK intensity $\left(I_{0}\right)$ and their distance to the lake $(d)$. The upper panel represents the seismic intensity triggered by the strongest and/or closest historical earthquakes in the lake area.

\section{Discussion}

\subsection{Lago Inferiore de Laures sediments: a record of past earthquakes?}

\subsubsection{Trigger of MSB, HB, GB-III and the deformed layer}

The MSB pattern in the Passega-type diagram suggests that the transport energy is supplied by the sediment weight rather than by a water current velocity, i.e. formation of concentrated density flows of suspended sediments during a subaquatic mass movement (e.g. Mulder and Cochonnat, 1996; Arnaud et al., 2002; Wilhelm et al., 2016b). The HB characteristics are very similar to deposits previously described by many studies (e.g. Schnellmann et al., 2005; Beck, 2009, Petersen et al., 2014). These studies proposed that a subaquatic mass movement triggers the oscillation of the whole lake water body (i.e. seiche), which homogenizes the sediment put in suspension by either the water oscillation or the mass move- ment. Therefore, HB most probably results also from a mass movement.

GBs are associated with turbidity currents triggered by either flood events or mass movements (e.g. Sturm and Matter, 1978; Shiki et al., 2000; Arnaud et al., 2002; Mulder and Chapron, 2011; Wilhelm et al., 2012b). In the latter case, they are formed by the sediment that is transported in suspension during the mass movement and then deposited over the mass-wasting deposits and/or further in the lake basin (e.g. Shiki et al., 2000; Schnellmann et al., 2005). These mass-movement-induced GBs are also known to be generally thicker than those induced by flood events because mass movements may mobilize much larger quantities of sediments than floods (e.g. Shiki et al., 2000; Schnellmann et al., 2005; Fanetti et al., 2008; Wilhelm et al., 2013). Accordingly, the rare GB-III characterized by large thicknesses may be associated with mass movements. The position of GB-IIIb on top of the deformed layer (Fig. 3) further supports this assumption because (i) the immediate stratigraphic succession suggests a common trigger for these two deposits and (ii) the ability of strong earthquake shaking to trigger (coseismic) in situ deformation and (post-seismic) mass movements. Folded and mixed beds of the deformed layer are similar characteristics to the so-called "mixed layers" that result from shear stress applied to poorly consolidated sediments during strong earthquake shaking (e.g. Marco et al., 1996; Rodriguez-Pascua et al., 2010; Migowski et al., 2004; Monecke et al., 2004). Accordingly, the deformed layer is interpreted as the result of strong earthquake shaking. Because of the immediate stratigraphic succession with the GB-IIIb, these two beds are interpreted as one event layer triggered by a common earthquake.

\subsubsection{Chronological control on the mass-movement-induced layers}

Mass movements can be triggered by spontaneous failures due to overloading of slope sediments, snow avalanches, fluctuations in lake levels, rockfalls or earthquakes (e.g. Van Daele et al., 2015; Wilhelm et al., 2016b). Here changes of lake level can be excluded because the water level of Lago Inferiore is well controlled by a bedrock outlet. Rockfalls seem also unlikely as there is no geomorphological evidence of major rockfalls in the catchment. Earthquakes are known to affect the region and may thus be a good candidate. In addition, the earthquake trigger is the only candidate to explain the in situ deformed layer with associated GB-IIIc. To test the earthquake trigger of all massmovement-induced layers (i.e. GB-III, HB and MSB), their ages are compared to the dates of well-documented historical earthquakes over the last centuries (database SisFrance, http://www.sisfrance.net; Lambert and Levret-Albaret, 1996; Scotti et al., 2004; and database CFTI4Med, http://storing. ingv.it/cfti4med/; Guidoboni et al., 2007). In addition to the chronological agreement, the potentially recorded earth- 
quakes are also expected to be the strongest and/or the closest to the lake, as those are expected to have generated the largest ground motions in the lake area. To take into account this second parameter, the seismic intensity of each historical earthquake in the lake area was estimated in first order by using the following equation from Wilhelm et al. (2016b):

$y=\alpha \cdot \ln (x)+b$,

where $x$ corresponds to the distance between the lake and the epicentre, $y$ to the epicentral intensity of the historical earthquakes, $\alpha$ to the slope of the attenuation curve fixed to 1.13 for the region, and $b$ to the local seismic intensity. From this estimation, nine earthquakes over the last 250 years triggered local seismic intensities above V (Fig. 7), i.e. intensities that may be strong enough to trigger seismically induced deposits (e.g. Moernaut et al., 2014; Howarth et al., 2014; Van Daele et al., 2015; Wilhelm et al., 2016b). GBIIIa and HB are dated to $1962 \pm 12$ and $1941 \pm 16$ years, respectively (Fig. 5). These dates correspond well to the two most recent and "strongest" historical earthquakes occurring in 1968 and 1946 (Figs. 1 and 7). The extrapolation of the ${ }^{210} \mathrm{~Pb}$-based sedimentation rate allows estimating ages of the older mass-movement-induced layers to 1891,1859 , 1826, 1811, 1780 and 1771 (Fig. 7). All of them correspond well to earthquakes expected to have triggered the largest ground motions in the lake area in 1887, 1855, 1817, 1808, 1785 and 1767. Age differences between deposits and associated historical earthquakes are lower than 5 years, except between GB-IIIc dated to 1826 and the 1817 Chamonix earthquake. Surprisingly, although as strong as the other earthquakes, the Chamonix earthquake (1905) does not seem to have triggered a deposit. Overall, this good temporal agreement highly supports that mass-movement-induced layers may have been triggered by historical earthquakes.

\subsubsection{Earthquake record and lake sensitivity}

The record of eight earthquakes over $\sim 270$ years (i.e. return period of $\sim 35$ years) suggests a high sensitivity of Lago Inferiore de Laures to earthquake shaking, as such a high frequency of earthquake-induced deposits has rarely been observed in the region (e.g. Guyard et al., 2007; Lauterbach et al., 2012; Simonneau et al., 2013; Strasser et al., 2013; Kremer et al., 2015; Chapron et al., 2016; Wilhelm et al., 2016b). All historical earthquakes are plotted in a "distance vs. epicentral MSK intensity" diagram (e.g. Monecke et al., 2004; Wilhelm et al., 2016b) where the recorded earthquakes are highlighted in red (Fig. 8a). To quantify and compare its sensitivity to other lakes, an empirical threshold line was defined that limits the domains of the recorded from the nonrecorded earthquakes (blue line in Fig. 8a). The Earthquake Sensitivity Threshold Index (ESTI), defined as the inverse of the intercept of this threshold line with the intensity axis at $10 \mathrm{~km}$ from the lake (Wilhelm et al., 2016b), offers a direct comparison of sensitivity with these other lakes is possible.
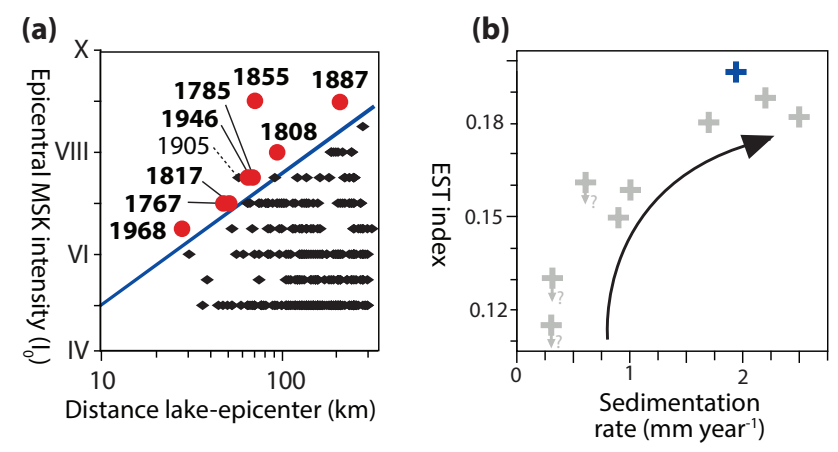

Figure 8. (a) Diagram of the distance of earthquakes to the lake vs. epicentral MSK intensity to confirm that the earthquakes associated with the mass-movement-induced deposits are the strongest and/or the closest to the lake. Black crosses indicate all historic earthquakes closer than $120 \mathrm{~km}$ to the lakes with epicentral MSK intensities $\geq$ IV. Red dots with dates correspond to historical earthquakes associated with the mass-movement-induced deposits in Fig. 7. The sensitivity threshold (blue line) is placed to delimit the recorded from the non-recorded earthquakes. (b) The Earthquake Sensitivity Threshold Index (ESTI) is compared to the sedimentation rate for Lago Inferiore de Laures (blue cross) and other similar Alpine lakes (grey crosses) studied by Wilhelm et al. (2016b). Arrows show that these ESTIs are maximum values.

The ESTI score for Lago Inferiore reaches 0.19, i.e. the highest value of the Alpine lakes for which the sensitivity was quantified (Fig. 8b). This high sensitivity of Lago Inferiore to earthquake shaking may be explained by many factors like slope angle, sediment thickness or geotechnical properties of the sedimentary succession (e.g. Morgenstern, 1967; Strasser et al., 2011; Ai et al., 2014; Wiemer et al., 2015). However, Wilhelm et al. (2016b) suggested that the dominant factor explaining the lake sensitivity of such Alpine lakes is the sedimentation rate, i.e. that the lake sensitivity increases when the sedimentation rate increases, which is in agreement with the lake's high sedimentation rate (Fig. 8b).

\subsection{Lago Inferiore de Laures sediments: a record of past floods?}

\subsubsection{Trigger of GB-I and GB-II}

The high frequency of GB-I (66 deposits over 270 years, return period of $\sim 4$ years) makes it unlikely that these layers were the result of mass movements. In addition, the very uniform values of grain size and thickness characterizing GB-I suggest that they are triggered by processes where sediment erosion, transport and deposition are well controlled/regulated. Many studies suggested that the amount and grain size of eroded, transported and deposited material in case of flood events are controlled by the river discharge (e.g. Schiefer et al., 2011; Lapointe et al., 2012; Jenny et al., 2014; Wilhelm et al., 2015). Therefore, flood processes seem to be the best candidate to trigger GB-I. 
The presence of grading in GB-II and their isolated positions in the "percentile vs. thickness" diagram are similar characteristics to GB-III and HB, suggesting a common trigger for both GB-II and GB-III, i.e. mass movements. The two GB-II are dated to $2006 \pm 2$ and $1997 \pm 4$ years, respectively (Fig. 5). An earthquake trigger is very unlikely as no strong and/or close earthquake occurred at that time. A mass-movement trigger can, however, not be excluded. Alternatively, Giguet-Covex et al. (2011) suggested that thickness of flood-induced GBs may significantly increase without changes in grain size when human impact, i.e. grazing pressure in such high-elevation catchments, became high. Sheep grazing and trampling would accelerate the mechanical soil degradation, making erosion processes higher during floods. In this way, GB-II may also be triggered by floods at times of high grazing activity, which currently occurs close to the lake as evidenced by the sheep pen located on the shoreline of Lago Inferiore. In addition, these deposits appear in the uppermost part of the cores characterized by high organic matter content. This higher content of lacustrine organic matter might result from a higher primary production linked to an increase of nutrients inputs with the higher grazing activity.

\subsubsection{Chronological control on flood-induced deposits}

The assignment of a flood trigger to GB-I and GB-II may be assessed by using historical flood data. A direct comparison between deposit ages and historical flood dates is precluded because the outlet stream of Lago Inferiore does not flow through any village downstream. Instead, the frequency of GB-I and GB-II occurrences was compared to the frequency of historical summer-autumn floods that affected streams and villages around Lago Inferiore as documented by Mercalli et al. (2003). For the comparison, a historical flood event that occurred in mid-May (1926) was not considered as we assume that the lake was frozen at that time. Over the last century, historical data reveal a high flood frequency (up to four floods per 11 years) during periods 1900-1920 and 1950-2010 and a low frequency (less than one flood per 11 years) during the period 1920-1950 (Fig. 9). This multidecadal variability in flood frequency is well reproduced by the sediment record when considering both GB-I and GB-II. Indeed, both the three time periods and the range of floodfrequency values (from 1 to 4 per 11 years) are very similar between records. If GB-II is removed from the sediment record, the reconstructed flood frequency shows a more pronounced decrease over the last decades (orange line in Fig. 9) than in the historical record. This may support a flood trigger (during a period of high grazing activity) for GB-II. Overall, the good agreement with the historical data, when considering both GB-I and GB-II, supports the fact that Lago Inferiore sediments are a good recorder of the decadal variability of past floods.

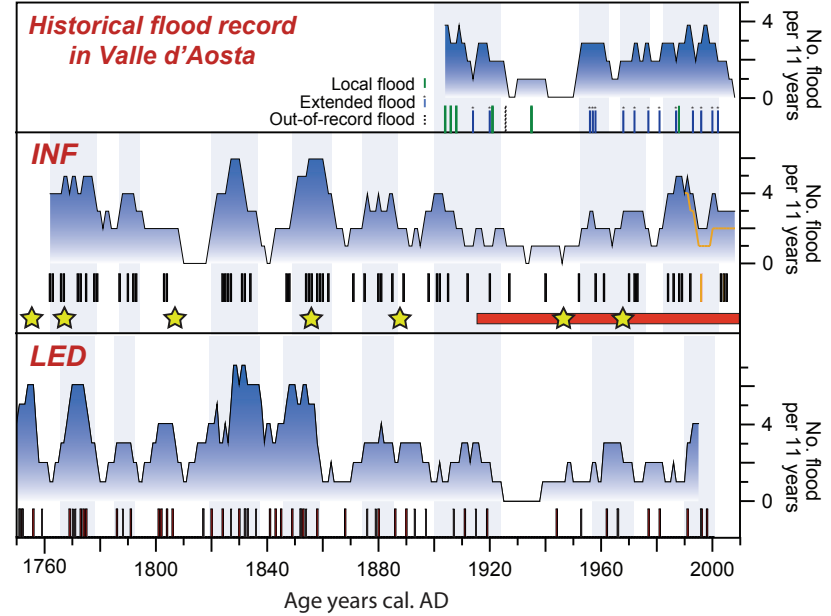

Figure 9. Comparison of the reconstructed Lago Inferiore de Laures (INF) flood frequency (11-year running sum) with the frequency (11-year running sum) of historical floods in Aosta Valley (Mercalli et al., 2003) and the frequency of summer-autumn floods recorded in Lago di Ledro (LED; Wirth et al., 2013). Vertical bars correspond to flood occurrences. For Lago Inferiore de Laures, the two orange vertical bars correspond to the GB-II. The orange curve corresponds to the flood frequency when these two deposits are not considered. Yellow stars correspond to the earthquake-induced deposits indicated as chronological markers and the horizontal red rectangle highlights the period dated by the $210 \mathrm{~Pb}$ method. For the Lago di Ledro record, black vertical bars correspond to summer floods and red vertical bars to autumn floods.

\subsubsection{Palaeoflood record in the regional climatic setting}

Historical data revealed that flood events mostly occurred in summer and autumn (20 of 21), i.e. during the ice-free season of the lake. Hence, the variability of floods that impacted communities in Valle d'Aosta is well represented by the flood activity recorded in the Lago Inferiore sediment sequence. Among these events, five occurred in summer and early autumn and affected a localized area (i.e. only one mountain stream; Mercalli et al., 2003). According to the season and their limited spatial extent, these events are most probably triggered by local convective events, i.e. thunderstorms. The 15 other events occurred equally in summer and autumn and affected many tributaries and/or the main Dora Baltea River. As these events affected large catchments (ca. $200-2000 \mathrm{~km}^{2}$ ), they are most probably related to mesoscale convective events typical of the Mediterranean climate (e.g. Buzzi and Foschini, 2000). Therefore, the flood activity recorded in Lago Inferiore sediments is mainly related to large-scale hydro-meteorological events and may represent a "regional" signal of the past summer-autumn flood variability. As these mesoscale events are formed by humid air masses from the Mediterranean that flow northward through the Po Plain to the Alps (e.g. Buzzi and Foschini, 
2000), they may also trigger floods in many Alpine regions located north of the Po Plain.

To test the "regional" character of the reconstructed flood signal, the Lago Inferiore de Laures flood record was compared to the Lago di Ledro flood record. Lago di Ledro is a low-elevation lake (660 m a.s.l.) located $280 \mathrm{~km}$ east from Lago Inferiore de Laures, in the eastern part of the Alpine region located north to the Po Plain (Fig. 1). Floods in Ledro catchment $\left(111 \mathrm{~km}^{2}\right)$ also occur mainly in summer and autumn due to mesoscale convective events (Wirth et al., 2013). The extrapolation of the sedimentation rate enables to extend the centennial Lago Inferiore de Laures flood record to the last 270 years (Fig. 7). From the comparison with the Lago di Ledro flood record (Fig. 9), we observe that the range of flood-frequency values is in agreement between the two records, i.e. between zero and six floods per 11 years. Secondly, we observe strong similarities in the two flood records with periods of high flood frequency in 1760-1780, 1785$1795,1820-1835,1875-1885,1955-1975$ and after 1990 and periods of low flood frequency in 1780-1785, 18101820, 1860-1875 and 1925-1955. However, some discrepancies between the two records can be noticed around 1800 , 1890-1920 and 1980-1990. They may be related to localized events, e.g. thunderstorms, which may have different spatial and temporal dynamics between sites as evidenced by the record of several local floods between 1900 and 1910 (Fig. 9). Overall, there is a good agreement in the main trends of the flood frequencies, suggesting that the two flood records dominantly represent the decadal variability of mesoscale convective events triggering floods in this part of the Mediterranean Alps.

\section{Conclusion}

The high-resolution sedimentological study of Lago Inferiore de Laures revealed 77 beds that correspond to 76 event layers over the last ca. 270 years. A detailed analysis suggested that 8 of 76 event layers are related to 8 massmovement events, while 66 of 76 are most probably related to flood events. The trigger of two event layers (those labelled GB-II) still remains uncertain. The temporal assignment suggests a flood trigger during a period of high grazing activity. However, further work is still required to confirm this hypothesis, e.g. by studying proxy of grazing activity like coprophilous fungal ascospores (e.g. Davis and Schafer, 2006; Etienne et al., 2013).

The eight mass movements were chronologically compared to the well-documented historical seismicity. The comparison revealed that mass movements in Lago Inferiore de Laures are most probably triggered by strong (epicentral MSK intensity of VI-IX) and/or close (distance to the lake of 25-120 km) earthquakes. Compared to other Alpine lakes, the high frequency of earthquake-induced mass movements (eight over ca. 270 years) suggested a high sensitivity of
Lago Inferiore de Laures sediments to earthquake shaking. Indeed, this lake appeared to be regionally the most sensitive, with an ESTI value of 1.9, which may be explained by its high sedimentation rate.

The frequency of flood-induced deposits was compared to the frequency of historical summer-autumn floods that affected mountain streams and rivers in Valle d'Aosta. This showed that the (multi-)decadal frequency of flood events that impacted local populations is well reproduced by the sedimentary record. The comparison with the flood record of Lago di Ledro, located $280 \mathrm{~km}$ east, suggested that the main trends of the (multi-)decadal flood variability are in good agreement between records, suggesting a "regional" character of the two reconstructed flood signals linked to the typical Mediterranean mesoscale precipitation events.

Hence, this study showed that Lago Inferiore de Laures sediments seem to be a remarkable record of earthquakes and floods, both natural hazards harming populations of this Alpine region. This should encourage further study to extend the Lago Inferiore de Laures record further back in time. Such a long-term record of natural hazards would improve our knowledge on the natural hazard occurrence and, thereby, enable a better risk assessment.

Data availability. No data sets were used in this article.

Competing interests. The authors declare that they have no conflict of interest.

Acknowledgements. B. Wilhelm's post-doctoral fellowship (20132014) was supported by a grant from the AXA Research Fund. We would also like to thank Pierre Sabatier for his help to interpret the ${ }^{210} \mathrm{~Pb}$ data. The authors thank Marteen Van Daele and the anonymous reviewer for their constructive and helpful comments.

Edited by: V. Kotroni

Reviewed by: M. Van Daele and one anonymous referee

\section{References}

Ai, F., Strasser, M., Preu, B., Hanebuth, T. J. J., Krastel, S., and Kopf, A.: New constraints on the oceanographic vs. seismic control on submarine landslides initiation: A geotechnical approach off Uruguay and northern Argentina, Geo Mar. Lett., 34, 399417, 2014.

Amann, B., Sönke, S., and Grosjean, M.: A millennial-long record of warm season precipitation and flood frequency for the Northwestern Alps inferred from varved lake sediments: implications for the future, Quaternary Sci. Rev., 115, 89-100, 2015.

Appleby, P. G., Richardson, N., and Nolan, P. J.: 241Am dating of lake sediments, Hydrobiologia, 214, 35-42, 1991.

Arnaud, F., Lignier, V., Revel, M., Desmet, M., Pourchet, M., Beck, C., Charlet, F., Trentesaux, A., and Tribovillard, N.: Flood and 
earthquake disturbance of $210 \mathrm{~Pb}$ geochronology (Lake Anterne, North French Alps), Terra Nova, 14, 225-232, 2002.

Arnaud, F., Revel-Rolland, M., Bosch, D., Winiarski, T., Chapron, E., Desmet, M., Tribovillard, N., and Givelet, N.: A reliable 300 years-long history of lead contamination in Northern French Alps from distant lake sediment records, J. Environ. Monit., 6, 448-456, 2004.

Avşar, U., Hubert-Ferrari, A., De Batist, M., Lepoint, G., Schmidt, S., and Fagel, N.: Seismically-triggered organic-rich layers in recent sediments from Göllüköy Lake (North Anatolian Fault, Turkey), Quaternary Sci. Rev., 103, 67-80, 2014.

Ballesteros-Cánovas, J. A., Stoffel, M., St George, S., and Hirschboeck, K.: A review of flood records from tree rings, Prog. Phys. Geog., 39, 794-816, 2015.

Beck, C.: Late Quaternary lacustrine paleo-seismic archives in north-western Alps: Examples of earthquake-origin assessment of sedimentary disturbances, Earth Sci. Rev., 96, 327-344, 2009.

Benito, G., Macklin, M. G., Panin, A., Rossato, S., Fontana, A., Jones, A. F., Machado, M. J., Matlakhova, E., Mozzi, P., and Zielhofer, C.: Recurring flood distribution patterns related to shortterm Holocene climatic variability, Science reports, 5, 1-8, 2015.

Boschi, E., Guidoboni, E., Ferrari, G., Mariotti, D., Valensise, G., and Gasperini, P.: Catalogue of Strong Italian Earthquakes, Ann. Geofis., 43, 609-868, 2000.

Brázdil, R., Kundzewicz, Z. W., Benito, G., Demarée, G., Macdonald, N., and Roald, L. A.: Historical floods in Europe in the past Millennium, in: Changes in Flood Risk in Europe, edited by: Kundzewicz, Z. W., IAHS Press, Wallingford, 121-166, 2012.

Buzzi, A. and Foschini, L.: Mesoscale meteorological features associated with heavy precipitation in the Southern Alpine Region, Meteorol. Atmos. Phys., 72, 131-146, 2000.

Chapron, E., Simonneau, A., Ledoux, G., Arnaud, F., Lajeunesse, P., and Albéric, P.: French Alpine Foreland Holocene Paleoseismicity Revealed by Coeval Mass Wasting Deposits in Glacial Lakes, in: Submarine Mass Movements and their Consequences, edited by: Lamarche, G., Mountjoy, J., Bull, S., Hubble, T., Krastel, S., Lane, E., Micallef, A., Moscardelli, L., Mueller, C., Pecher, I., and Woelz, S., Advances in Natural and Technological Hazards Research, 41, 341-349, 2016.

Croudace, I. W., Rindby, A., and Rothwell, R. G.: ITRAX: description and evaluation of a new multi-function X-ray core scanner, in: New Techniques in Sediment Core Analysis, edited by: Rothwell, R. G., Geological Society, London, Special Publications, 367, 51-63, 2006.

Davis, O. K. and Schafer, D.: Sporormiella fungal spores, a palynological means of detecting herbivore density, Palaeogeogr. Palaeoclimatol. Palaeoecol., 237, 40-50, 2006.

Denniston, R. G., Villarini, G., Gonzales, A. N., Wyrwoll, K. H., Polyak, V. J., Ummenhofer, C. C, Lachniet, M. S., Wanamaker Jr., A. D., Humphreys, W. F., Woods, D., and Cugley, J.: Extreme rainfall activity in the Australian tropics reflects changes in the El Niño/Southern Oscillation over the last two millennia, P. Natl. Acad. Sci. USA, 112, 4576-4581, 2015.

Etienne, D., Wilhelm, B., Sabatier, P., Reyss, J.-L., and Arnaud, F.: Influence of sample location and livestock numbers on Sporormiella concentrations and accumulation rates in surface sediments of Lake Allos, French Alps, J. Paleolimnol., 49, 117127,2013
Eva, C., Barani, S., Carenzo, G., De Ferrari, R., Eva, E., Ferretti, G., Pasta, M., Pavan, M., Scafidi, D., Solarino, S., Spallarossa, D., Turino, C., and Zunino, E.: 30 years of seismicity in the South-western Alps and Northern Apennines as recorded by the Regional Seismic network of Northwestern Italy, Proceedings of GNGTS 2010, Prato, Italy, 2010.

Fäh, D., Giardini, D., Kästli, P., Deichmann, N., Gisler, M., Schwarz-Zanetti, G., Alvarez-Rubio, S., Sellami, S., Edwards, B., Allmann, B., Bethmann, F., Wössner, J., Gassner-Stamm, G., Fritsche, S., and Eberhard, D.: ECOS-09 Earthquake Catalogue of Switzerland Release 2011, Report and Database, Public catalogue, 17 April 2011, Swiss Seismological Service ETH Zürich, Report SED/RISK/R/001/20110417, 2011.

Fanetti, D., Anselmetti, F. S., Chapron, E., Sturm, M., and Vezzoli, L.: Megaturbidite deposits in the Holocene basin fill of Lake Como (southern Alps, Italy), Palaeogeogr. Palaeoclimatol. Palaeoecol., 259, 323-340, 2008.

Gani, M. R.: From turbid to lucid: A straightforward approach to sediment gravity flows and their deposits, Sediment. Rec., 2, 4 8, 2004

Gaume, E., Bain, V., Bernardara, P., Newinger, O., Barbuc, M., Bateman, A., Blaškovicčová, L., Blöschl, G., Borga, M., Dumitrescu, A., Daliakopoulos, I., Garcia, J., Irimescu, A., Kohnova, S., Koutroulis, A., Marchi, L., Matreata, S., Medina, V., Preciso, E., Sempere-Torres, D., Stancalie, G., Szolgay, J., Tsanis, I., Velasco, D., and Viglione, A.: A collation of data on European flash floods, J. Hydrol., 367, 70-78, 2009.

Giguet-Covex, C., Arnaud, F., Poulenard, J., Disnar, J. R., Delhon, C., Francus, P., David, F., Enters, D., Rey, P.-J., and Delannoy, J.-J.: Changes of erosion patterns during the Holocene in a currently treeless subalpine catchment inferred from lake sediment geochemistry (Lake Anterne, $2063 \mathrm{~m}$ asl, NW French Alps), Holocene, 21, 651-665, 2011.

Gilli, A., Anselmetti, F. S., Glur, L., and Wirth, S. B.: Lake sediments as archives of recurrence rates and intensities of past flood events, in: Dating Torrential Processes on Fans and Cones - Methods and Their Application for Hazard and Risk Assessment, edited by: Schneuwly-Bollschweiler, M., Stoffel, M., and Rudolf-Miklau, F., Adv. Glob. Change Res., 47, 225-242, 2012.

Goldberg, E. D.: Geochronology with 210Pb Radioactive Dating, IAEA, Vienna, 121-131, 1963.

Guidoboni, E., Ferrari, G., Mariotti, D., Comastri, A., Tarabusi, G., and Valensise, G.: Catalogue of strong earthquakes in Italy 461B.C.-1997 and Mediterranean area 760 B.C.-1500, 2007, available at: http://storing.ingv.it/cfti4med (last access: 18 October 2016), 2007.

Guyard, H., Chapron, E., St-Onge, G., Anselmetti, F. S., Arnaud, F., Magand, O., Francus, P., and Melières, M. A.: High-altitude varve records of abrupt environmental changes and mining activity over the last 4000 years in the Western French Alps (Lake Bramant, Grandes Rousses Massif), Quaternary Sci. Rev. 26, 2644-2660, 2007.

Guzzetti, F. and Tonelli, G.: Information system on hydrological and geomorphological catastrophes in Italy (SICI): a tool for managing landslide and flood hazards, Nat. Hazards Earth Syst. Sci., 4, 213-232, doi:10.5194/nhess-4-213-2004, 2004.

Howarth, J. D., Fitzsimons, S. J., Norris, R. J., and Jacobsen, G. E.: Lake sediments record high intensity shaking that provides insight into the location and rupture length of large earthquakes 
on the Alpine Fault, New Zealand, Earth Planet. Sc. Lett., 403, 340-351, 2014

IPCC: The Physical Science Basis, Contribution of Working Group I to the Fifth Assessment Report of the Intergovernmental Panel on Climate Change, edited by: Stocker, T. F., Qin, D., Plattner, G.-K., Tignor, M., Allen, S. K., Boschung, J., Nauels, A., Xia, Y., Bex, V., and Midgley, P. M., Cambridge University Press, Cambridge, United Kingdom and New York, NY, USA, 2013.

Jenny, J.-P., Wilhelm, B., Arnaud, F., Sabatier, P., Giguet-Covex, C., Mélo, A., Fanget, B., Malet, E., Ployon, E., and Perga, M. E.: A 4D sedimentological approach to reconstructing the flood frequency and intensity of the Rhône River (Lake Bourget, NW European Alps), J. Paleolimnol., 51, 469-483, 2014.

Kremer, K., Corella, J. P., Adatte, T., Garnier, E., Zenhäusern, G., and Girardclos, S.: Origin of turbidites in deep Lake Geneva (France-Switzerland) in the last 1500 years, J. Sed. Res., 85, 1455-1465, 2015.

Lambert, J. and Levret-Albaret, A.: Mille ans de Séismes en France, Catalogues d'Épicentres, Paramètres et Références, Ouest-Editions ed., 78 pp., Presses Académiques, Nantes, 1996.

Lapointe, F., Francus, P., Lamoureaux, S. F., Said, M., and Cuven, S.: 1,750 years of large rainfall events inferred from particle size at East Lake, Cape Bounty, Melville Island, Canada, J. Paleolimnol., 48, 159-173, 2012.

Larroque, C., Scotti, O., and Ioualalen, I.: Reappraisal of the 1887 Ligurian earthquake [western Mediterranean] from macroseismicity, active tectonics and tsunami modelling, Geophys. J. Int., 190, 87-104, 2012.

Lauterbach, S., Chapron, E., Hüls, M., Gilli, A., Arnaud, F., Piccin, A., Nomade, J., Desmet, M., von Grafenstein, U., and DecLakes Participants: A sediment record of Holocene surface runoff events and earthquake activity from Lake Iseo (Southern Alps, Italy), Holocene, 22, 749-760, 2012.

Lionello, P., Abrantes, F., Congedi, L., Dulac, F., Gacic, M., Gomis, D., Goodess, C., Hoff, H., Kutiel, H., Luterbacher, J., Planton, S., Reale, M., Schröder, K., Struglia, M. V., Toreti, A., Tsimplis, M., Ulbrich, U., and Xoplaki, E.: Introduction: Mediterranean Climate: Background Information, edited by: Lionello, P., The Climate of the Mediterranean Region, From the Past to the Future, Amsterdam, Elsevier, Netherlands, XXXV-1XXX, ISBN: 9780124160422, 2012.

Marchi, L., Borga, M., Preciso, E., and Gaume E.: Characterisation of selected extreme flash floods in Europe and implications for flood risk management, J. Hydrol., 394, 118-133, 2010.

Marco, S., Stein, M., Agnon, A., and Ron, H.: Long-term earthquake clustering: A 50,000 year paleoseismic record in the Dead Sea Graben, J. Geophys. Res.-Sol. Ea., 101, 6179-6191, 1996.

Mercalli, L., Cat Berro, D., Montuschi, S., Castallano, C., Ratti, M., Di Napoli, G., Mortara, G., and Guidani, N.: Atlante climatico della Valle d'Aosta, Societa Meteorolgica Subalpina, Torino, 2003.

Migowski, C., Agnon, A., Bookman, R., Negendank, J. F. W., and Stein, M.: Recurrence pattern of Holocene earthquakes along the Dead Sea transform revealed by varve-counting and radiocarbon dating of lacustrine sediments, Earth Planet. Sci. Lett., 222, 301314, 2004.

Moernaut, J., Van Daele, M., Heirman, K., Fontijn, K., Strasser, M., Pino, M., Urrutia, R., and De Batist, M.: Lacustrine turbidites as a tool for quantitative earthquake reconstruction: New evidence for a variable rupture mode in south central Chile, J. Geophys. Res.-Sol. Ea., 119, 1607-1633, 2014.

Monecke, K., Anselmetti, F. S., Becker, A., Sturm, M., and Giardini, D.: The record of historic earthquakes in lake sediments of Central Switzerland, Tectonophysics, 394, 21-40, 2004.

Morgenstern, N. R.: Submarine Slumping and Initiation of Turbidity Currents, edited by: Richards, A. F., 189-220, Mar. Geotechnique UP, Urbana, Ill, 1967.

Mulder, T. and Chapron, E.: Flood deposits in continental and marine environments: Character and significance, in: Sediment Transfer From Shelf to Deep Water-Revisiting the Delivery System RM, edited by: Zavala, S. C., AAPG Stud. Geol., 61, 1-30, 2011.

Mulder, T. and Cochonat, P.: Classification of offshore mass movements, J. Sediment. Res., 66, 43-57, 1996.

Munich Re Group: Annual review: natural catastrophes 2002, Münich Re Group, Münich, p. 62, 2003.

Passega, R.: Grain-size representation by CM patterns as a geological tool, J. Sediment. Petrol., 34, 830-847, 1964.

Petersen, J., Wilhelm, B., Revel, M., Rolland, Y., Crouzet, C., Arnaud, F., Brisset, E., Chaumillon, E., and Magand, O.: Sediments of Lake Vens (SW European Alps, France) record largemagnitude earthquake events, J. Paleolimnol., 51, 343-355, 2014.

Renberg, I., Bindler, R., and Bränvall, M. L.: Using the historical atmospheric lead-deposition record as a chronological marker in sediment deposits in Europe, Holocene, 11, 511-516, 2001.

Ratto, S., Bonetto, F., and Comoglio, C.: The October 2000 flooding in Valle d'Aosta (Italy): Event description and land planning measures for the risk mitigation, International Journal of River Basin Management, 1, 105-116, 2003.

Ratzov, G., Cattaneo, A., Babonneau, N., Déverchère, J., Yelles, K., Bracene, R., and Courboulex, F.: Holocene turbidites record earthquake supercycles at a slow-rate plate boundary, Geology, 43, 331-334, 2015.

Rizza, M., Ritz, J. F., Braucher, R., Vassallo, R., Prentice, C., Mahan, S., and Demberel, S.: Slip rate and slip magnitudes of past earthquakes along the Bogd left-lateral strike-slip fault (Mongolia), Geophys. J. Int., 186, 897-927, 2011.

Rodriguez-Pascua, M. A., Garduno-Monroy, V. H., IsradeAlcantara, I., and Pérez-Lopez, R.: Estimation of the paleoepicentral area from the spatial gradient of deformation in lacustrine seismites (Tierras Blancas Basin, Mexico), Quat. Int., 219, 66-78, 2010.

Schiefer, E., Gilbert, R., and Hassan, M. A.: A lake sediment-based proxy of floods in the Rocky Mountain Front Ranges, Canada, J. Paleolimnol., 45, 137-149, 2011.

Schillereff, D. N., Chiverrell, R. C., Macdonald, N., and Hooke, J. M.: Flood stratigraphies in lake sediments: A review, Earth-Sci. Rev., 135, 17-37, 2014.

Schillereff, D. N., Chiverrell, R. C., Macdonald, N., and Hooke, J. M.: Hydrological thresholds and basin control over paleoflood records in lakes, Geology, 44, 43-46, 2016.

Schmidt, S., Howa, H., Diallo, A., Martín, J., Cremer, M., Duros, P., Fontanier, C., Deflandre, B., Metzger, E., and Mulder, T.: Recent sediment transport and deposition in the Cap-Ferret Canyon, South-East margin of Bay of Biscay, Deep Sea Research II, 104, 134-144, doi:10.1016/j.dsr2.2013.06.004, 2014. 
Schnellmann, M., Anselmetti, F. S., Giardini, D., and McKenzie, J. A.: Mass-movement-induced fold-and-thrust belt structures in unconsolidated sediments in Lake Lucerne (Switzerland), Sedimentology, 52, 271-289, 2005.

Scotti, O., Baumont, D., Quenet, G., and Levret, A.: The French macroseismic database SISFRANCE: Objectives, results and perspectives, Ann. Geophys., 47, 571-581, 2004.

Shiki, T., Kumon, F., Inouchi, Y., Kontani, Y., Sakamoto, T., Tateishi, M., and Fukuyama, K.: Sedimentary features of the seismo-turbidites, Lake Biwa, Japan, Sediment. Geol., 135, 37$50,2000$.

Simonneau, A., Chapron, E., Vannière, B., Wirth, S. B., Gilli, A., Di Giovanni, C., Anselmetti, F. S., Desmet, M., and Magny, M.: Mass-movement and flood-induced deposits in Lake Ledro, southern Alps, Italy: implications for Holocene palaeohydrology and natural hazards, Clim. Past, 9, 825-840, doi:10.5194/cp-9825-2013, 2013.

Støren, E. N., Olaf Dahl, S., Nesje, A., and Paasche, Ø.: Identifying the sedimentary imprint of high-frequency Holocene river floods in lake sediments: development and application of a new method, Quaternary Sci. Rev., 29, 3021-3033, 2010.

Strasser, M., Anselmetti, F. S., Donat, F., Giardini, D., and Schnellmann, M.: Magnitudes and source areas of large prehistoric northern Alpine earthquakes revealed by slope failures in lakes, Geology, 12, 1005-1008, 2006.

Strasser, M., Hilbe, M., and Anselmetti, F. S.: Mapping basin-wide subaquatic slope failure susceptibility as a tool to assess regional seismic and tsunami hazards, Mar. Geophys. Res., 32, 331-347, 2011.

Strasser, M., Monecke, K., Schnellmann, M., and Anselmetti, F. S.: Lake sediments as natural seismographs: A compiled record of Late Quaternary earthquakes in Central Switzerland and its implication for Alpine deformation, Sedimentology, 60, 319-341, 2013.

Sturm, M. and Matter, A.: Turbidites and varves in Lake Brienz (Switzerland): Deposition of clastic detritus by density currents, in: Modern and Ancient Lake Sediments, edited by: Matter, A. and Tucker, M. E., Int. Assoc. Sedimentol. Spec. Publ., 2, 147168, 1978.

Van Daele, M., Moernaut, J., Doom, L. , Boes, E. , Fontijn, K., Heirman, K., Vandoorne,W., Hebbeln, D., Pino, M., Urrutia, R., Brümmer, R., and De Batist, M.: A comparison of the sedimentary records of the 1960 and 2010 great Chilean earthquakes in 17 lakes: Implications for quantitative lacustrine palaeoseismology, Sedimentology, 62, 1466-1496, 2015.

Vannière, B., Magny, M., Joannin, S., Simonneau, A., Wirth, S. B., Hamann, Y., Chapron, E., Gilli, A., Desmet, M., and Anselmetti, F. S.: Orbital changes, variation in solar activity and increased anthropogenic activities: controls on the Holocene flood frequency in the Lake Ledro area, Northern Italy, Clim. Past, 9, 1193-1209, doi:10.5194/cp-9-1193-2013, 2013.
Weiss, D., Shotyk, W., Kramers, J. D., and Gloor, M.: Sphagnum mosses as archives of recent and past atmospheric lead deposition in Switzerland, Atmos. Environ., 33, 3751-3763, 1999.

Wiemer, G., Moernaut, J., Stark, N., Kempf, P., De Batptist, M., Pino, M., Urrutia, R., Ladrón de Guevara, B., Strasser, M., and Kopf, A.: The role of sediment composition and behavior under dynamic loading conditions on slope failure initiation: A study of a subaqueous landslide in earthquake-prone South-Central Chile, Int. J. Earth Sci., 104, 1439-1457, 2015.

Wilhelm, B., Arnaud, F., Sabatier, P., Crouzet, C., Brisset, E., Chaumillon, E., Disnar, J. R., Guiter, F., Malet, E., Reyss, J. L., Tachikawa, K., Bard, E., and Delannoy, J. J.: 1400 years of extreme precipitation patterns over the Mediterranean French Alps and possible forcing mechanisms, Quaternary Res., 78, 1-12, $2012 \mathrm{a}$.

Wilhelm, B., Arnaud, F., Enters, D., Allignol, F., Legaz, A., Magand, O., Revillon, S., Giguet-Covex, C., and Malet, E.: Does global warming favour the occurrence of extreme floods in $\mathrm{Eu}-$ ropean Alps? First evidences from a NW Alps proglacial lake sediment record, Clim. Change, 113, 63-581, 2012b.

Wilhelm, B., Arnaud, F., Sabatier, P., Magand, O., Chapron, E., Courp, T., Tachikawa, K., Fanget, B., Malet, E., Pignol, C., Bard, E., and Delannoy, J. J.: Palaeoflood activity and climate change over the last 1400 years recorded by lake sediments in the NW European Alps, J. Quaternary Sci., 28, 189-199, 2013.

Wilhelm, B., Sabatier, P., and Arnaud, F.: Is a regional flood signal reproducible from lake sediments?, Sedimentology, 62, 1103$1117,2015$.

Wilhelm, B., Vogel, H., Crouzet, C., Etienne, D., and Anselmetti, F. S.: Frequency and intensity of palaeofloods at the interface of Atlantic and Mediterranean climate domains, Clim. Past, 12, 299-316, doi:10.5194/cp-12-299-2016, 2016a.

Wilhelm, B., Nomade, J., Crouzet, C., Litty, C., Sabatier, P., Belle, S., and Anselmetti, F. S.: Quantified sensitivity of small lake sediments to record historic earthquakes: Implications for paleoseismology, J. Geophys. Res.-Earth, 121, 2-16, 2016 b.

Wirth, S. B., Gilli, A., Simonneau, A., Ariztegui, D., Vannière, B., Glur, L., Chapron, E., Magny, M., and Anselmetti, F. S.: A 2000year long seasonal record of floods in the southern European Alps, Geophys. Res. Lett., 40, 4025-4029, 2013. 